DOI $10.31168 / 0440-4.52$

\title{
THE MONTENEGRIN POET AND RULER, PETAR II PETROVICH NEGOSH
}

\section{Abstract:}

The article talks about the representative of the national revival of the Southern Slavs, Petar II Petrovich Negosh (1813-51), the ruler of Montenegro, poet and writer, who had a great influence on the development of the national identity of the Montenegrins. The main theme of his creativity was the struggle of the people against Ottoman Turkey. In his poems, dramas and lyrics, he outlined with great artistic persuasiveness the persistent national character of the Montenegrins and their cult of valor and heroic characteristics. Negosh's works enriched the national literature in terms of genre and made a great contribution to the development of expressive capabilities in the native language. His works are a part of the national picture of the world, many of them have been used in citations.

\section{Keywords:}

Negosh, Montenegro, poetry, classicism, romanticism.

АННОТАЦИЯ: А.Г. ШЕШЕКЕН». «ЧЕРНОГОРСКИЙ ПОЭТ И ПРАВИТЕЛЬ ПЕТАР II ПЕТРОВИЧ НЕГОШ».

В статье рассказывается о представителе эпохи Национального возрождения южных славян, Петре II Петровиче Негоше (1813-51) - правителе Черногории, поэте и писателе, оказавшем большое влияние на развитие национального самосознания черногорцев. Главной темой его творчества была борьба народа против османской Турции. В своих поэмах, драмах и лирике он с большой художественной убедительностью обрисовал стойкий национальный характер черногорцев и свойственный им культ доблести и геройства. Произведения Негоша обогатили национальную литературу в жанровом отношении и внесли большой вклад в развитие изобразительных возможностей родного языка. Произведения являются частью национальной картины мира, многие из них были разобраны на цитаты.

\section{Ключевые слова:}

Негош, Черногория, поэзия, классицизм, романтизм.

Detar II Petrovich Negosh (in Montenegr. - Petar Petrovič Njegoš, 1813-51)

is outstanding Montenegrin and Serbian poet and statesman of the first half of the 19th century, a bright representative of South Slavic romanticism. He belonged to the ruling Negosh dynasty. At birth he received the name Radivoy (Rade). After the death of his uncle, Petar I Petrovich-Negosh (1830), he became the lord of Montenegro, inheriting the highest secular and spiritual power, 
in connection with which he took monastic vows in 1831 and became an Archimandrite under the name of Petar II Petrovich. In 1833 in Russia he was consecrated as a Bishop; in 1844 the Synod of the Russian Orthodox Church elevated him to the rank of Metropolitan. Negosh's work brilliantly reflects the era of the national revival of the southern Slavs, which entered a decisive phase in their struggle for deliverance from Ottoman rule. Negosh's poems, dramas and lyrics depicted the persistent national character of the Montenegrins, the cult of valor and heroism (chojštva $i$ junaštva) peculiar to this people. His works enriched the national literature in terms of genre and made a great contribution to development of the

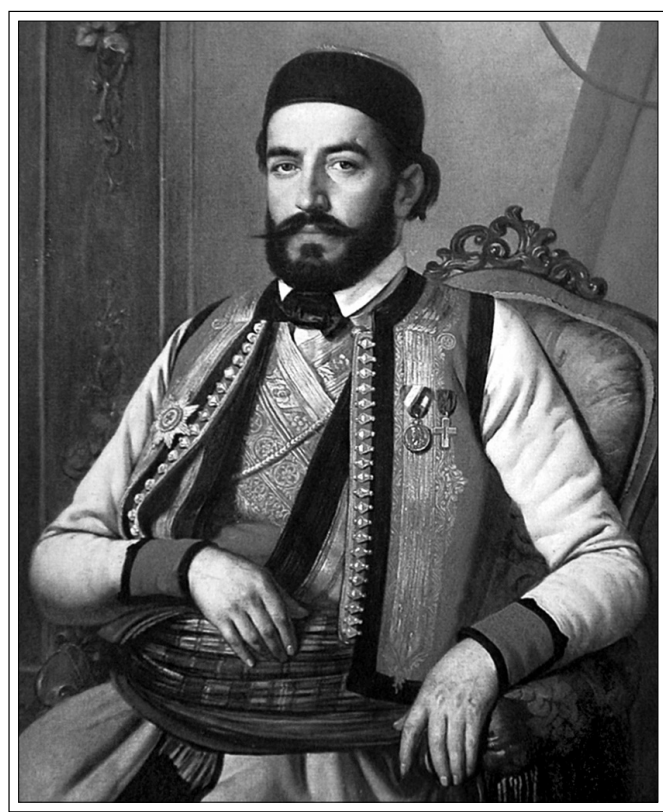

Aportrait of

Petar II P. Negosh native Montenegrin poetical language.

Negosh did not receive a systematic education, but he knew several foreign languages and had a wide knowledge in the fields of literature (from Homer, whom he translated, to Byron and Pushkin), history, philosophy and theology. A decisive influence on the formation of his creative personality was made by the educated and talented people from his inner circle: uncle, lord and poet Petar I Petrovich and the famous Serbian poet Sima Milutinovich-Sarayliya, who participated in the uprisings against the Turks. Russian literature had a great influence on him: in the poet's library there were works by such famous Russian authors as Lomonosov, Derzhavin, Pushkin and others. Negosh didn't have the opportunity to meet Pushkin in person, but when he visited Russia, he honored the memory of the great Russian poet by visiting his grave in 1837.

As a truly national poet, Negosh devoted all his work to the centuries-old confrontation between the Montenegrins and Ottoman Turkey, in which a small but persistent people remained undefeated. The poet's lyrics are distinguished by a deep, organic connection with folklore: his early poems were written in the spirit of folk poetry, using its imagery, size and rhythm. They were included in a collection published in 1834, Lijek jarosti turske ("The Cure for the Turkish Fury"). In a poem dedicated to A.S. Pushkin, Slobodijada ("The Freedom Song", 1835), Negosh described the Montenegrins' battles with numerous enemies Turks, Venetians and French - for more than a century, from 1711 to 1813. These works, and especially the collection's odes, Pustinjak Cetinje ("The Her- 
mit of Tsetinye", 1834), reflected such features of Negosh's poetry as a combination of classicism and romanticism inspired by the poetry of Lomonosov, Derzhavin and Mushitsky. The latter - romanticism - gradually started to prevail in Negosh's work.

This was reflected in his works of various genres, in particular in the epic philosophical poem Luča mikrokozma ("The Ray of the Microcosm", 1845). The poet writes in it about the creation of the world and of man, the latter's expulsion from paradise, and the battle of God the Creator and Satan. In terms of genre and type of narrative, it is close to the poem "Paradise Lost" by John Milton. The battle between the forces of light and darkness in it unfolds on a universal scale and develops with a tragic intensity of passion, for Satan is almost equal in power to God. The confrontation ends with the victory of the Creator, who illuminated the battlefield with his divine ray and defeated the forces of evil. In the poem, Negosh questions the origin of evil in the world and the reason for the suffering of man, while providing his own explanation for the circumstances of the expulsion of Adam and Eve from paradise. It differs from the biblical canon: according to the poet, the first man and his descendants believed in Satan and fought in the universal fateful battle of light and darkness on the side of evil. For this sin, like others, man must atone on earth. Negosh considers pride and envy to be the most terrible of sins, as they are directly related to the forces of destruction.

The pinnacle of Negosh's poetry is his poem Gorski Wijenac ("The Mountain Crown", 1847). It has been translated into many foreign languages and gained worldwide fame. Its dedication ("Ashes to the Father of Serbia") is addressed to the leader of the First Serbian Uprising (1804-13) Karageorgi. Negosh calls him "immortal", because he, "despite all obstacles, achieved a great goal: he raised the people in the name of the Cross, destroyed the barbarian chains, called the Serbs from the dead and breathed souls into the Serbs". The plot of "The Mountain Crown" is based on the dramatic clashes of the late 17 th and early 18th centuries, the historical period when the founder of the Negosh dynasty, Bishop Danilo, realized the need to unite all Montenegrins in fighting against the Turks. The most dangerous then were the compatriots, "Turchens", who converted to Islam and sided with the enemies invading the country, taking part in the ruin of the Mon-

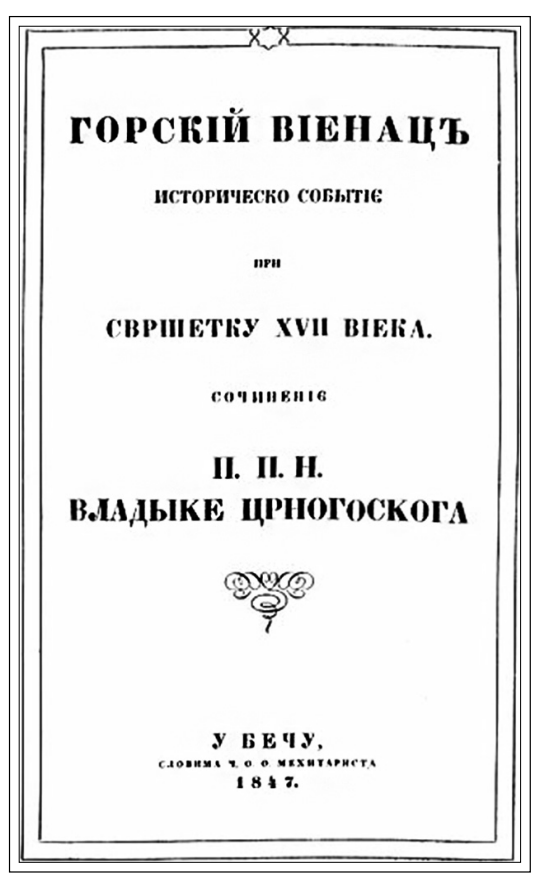

The cover of the first edition of "The Mountain Crown," 1847 
tenegrin city of Tsetinye and the Montenegrin spiritual capital - the Tsetinye monastery. Relying on the support of the people, Bishop Danilo decided to expel the Turchens from Montenegro. However, at the same time he experiences a tragic internal conflict. A sense of duty tells him to act decisively and harshly, but a desire to employ humane means makes him think about the tragedy of the coming conflict between compatriots: there is one blood, their faiths are different, but they are all Montenegrins. Danilo is afraid of many deaths and the custom of blood feud, which could wipe out all the Montenegrin people. However, the current situation leaves him no choice, and on Christmas Eve the traitors are expelled from Montenegro.

Among the poem's many vivid images, its main protagonist, the people, comes to the fore. All the major episodes of the poem are mass scenes in which the voices of representatives of the tribes and brotherhoods sound. The people's opinion is expressed in the song performed during the Kolo (round dance). The collective song, as a kind of choir of ancient Greek tragedy, offers an assessment of the events that have occurred, glorifies the dead and inspires people to victory. The proponent of the highest folk wisdom is the old blind abbot Stefan, who strengthens the Montenegrins' determination to defend their freedom: "die with glory, since you must die".

Negosh devotes much attention to portraying the national character of the Montenegrins. He tells of their history, recalls the glorious Nemanich kingdom, sees in his characters the descendants of the heroes of the Kosovo battle of 1389, who did not want to submit to the Turkish sultan, took refuge in the mountains and continued to fight for their faith. At the same time, the choir, in the spirit of folk poetry, blames princely strife for defeat in the Kosovo field. The Kosovo myth and the cult of the hero of the battle, the knight Milosh Obilich (who used his cunning to penetrate the tent of Sultan Murad I and stab him with in the midst of the battle), are an important part of "The Mountain Crown". Almost all the heroes of the poem see Milosh Obilichh in a dream in white robes on the eve of the decisive battle with the Turchens. The dream is interpreted by them as a good omen.

The author sees the purpose of his people in the stubborn struggle for freedom. The main element of the Montenegrin national character is the desire to be a warrior. After all, the Montenegrins, according to Negosh, are not capable of being, like the Venetians, successful merchants, or becoming prosperous artisans or farmers, for there is almost no fertile land in the country. The main attributes of heroes are their willingness to sacrifice and patriotism. For Montenegrins, the world of harsh mountains, nature, the sounds of dulcimers and songs glorifying heroes are absolute values. This world is contrasted with the Western world, using the example of Venice, which is depicted by the author satirically: it is stuffy, there is no air, men are all fat and pampered. The world of the East (Turkish) is no better, i.e., extremely alien to the Montenegrins. The poem provides many everyday details of the lives of the people: national costumes, 
customs, rites and superstitions. Montenegrins believe in dreams, although they often laugh at their interpretation, they divine on the bones of animals: a sheep's shoulder blade. The amusements of young people are described in the poem, as well as the high-spirited games that make future warriors bold and agile.

The title of the poem "The Mountain Crown" is a multi-layered metaphor. This is the crown of mountain peaks, among which the Slavic people live. At the same time, this is the crown of martyrdom: the mountains are littered with the bones of warriors who laid down their heads for a just cause. This is also the crown with which the winners are crowned: the author of the poem believes that his native people will overcome their enemies, and the heroes will remain in the bright memory of their descendants. This is the crown of young brides a hairstyle adorning the head of a young woman. However, such a crown is not worn for long - brides quickly become widows and, as a sign of mourning, cut off their hair (there is an episode about this in the poem). The intensity of tragedy in such episodes is achieved due to the elevated tone and the solemnity of sound, emphasized by the use of Church Slavonic vocabulary. At the same time, some episodes are colored with humor, jokes and the sound of laughter, which brings to the text the immediacy of lively colloquial speech. The abundance of aphoristic sayings in the poem has led to the widespread use of quotations in the everyday speech of Montenegrins. "The Mountain Crown" is still one of the most famous and beloved works in Montenegro, and many can quote entire passages from this poem by heart.

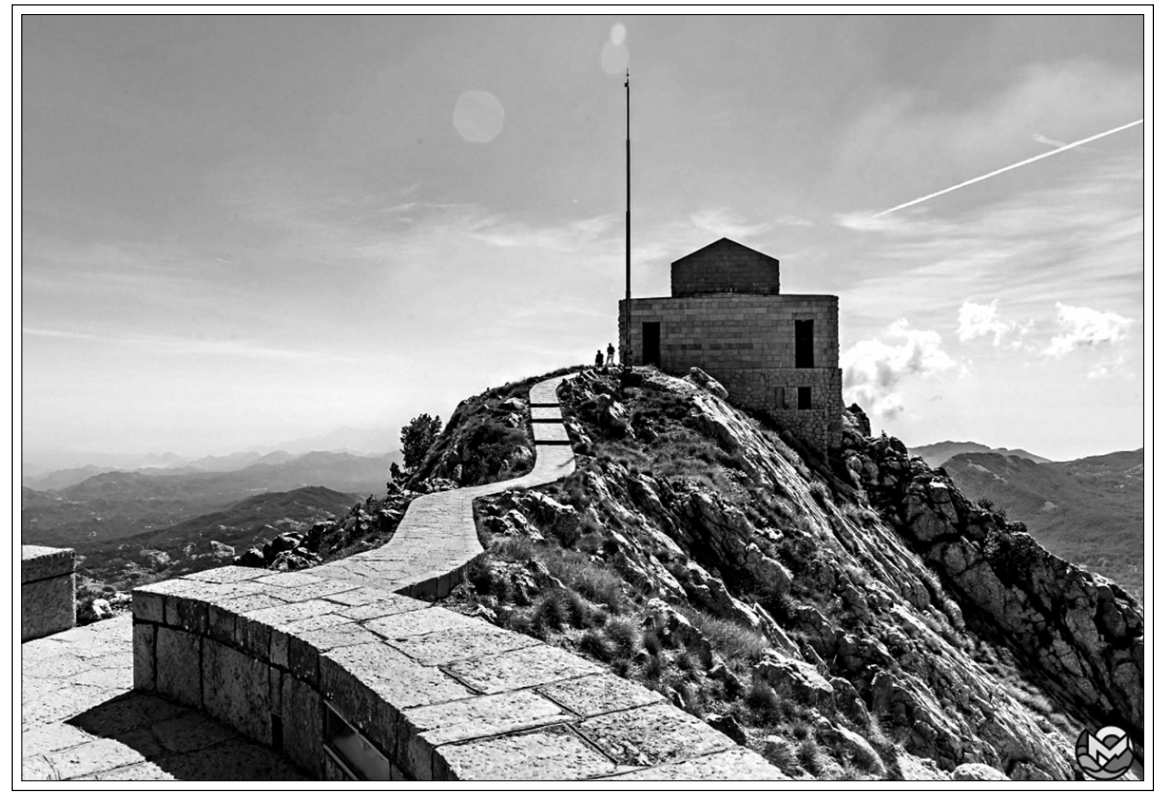

The Mausoleum of Petar P. Negosh in Lovchen, Montenegro 
Montenegrins' traditional sympathies for Russia are reflected in almost all of the writer's works, including the last of them. This is the historical drama Lažni car Scepan Mali ("The Impostor Stepan the Small", 1847), which talks about the historical events of the last quarter of the 18th century. It was then that an impostor appeared in Montenegro, posing as the Russian Tsar Peter III. The Montenegrins recognized his royal title and entrusted him with the government of the country. The impostor took the name Stepan (the name of one of the representatives of the Serbian Nemanich dynasty) and ruled Montenegro for six years, from 1767 to 1773. Stepan Mali was not forgotten by the people, who "recalled only what was precious", but almost no documents about him have been preserved. Negosh based his tragedy on "folk tradition" and on documents found in Venetian archives, but "he himself added nothing". The author refers to this historical fact, "in view of the importance of the event and its singularity". In the preface to the publication, he wrote: "Stepan Mali was a liar and a vagabond, but his reign under the name of the Russian tsar became a famous era for Montenegro and its neighbors". Stepan laid the foundations of the modern state system, built the judicial system, installed memorials in honor of the major victories of the Montenegrins over the Turks. The Montenegrins rallied around the liar, which caused great concern among hostile neighbors. The Venetian Republic and the Turks tried to force the Montenegrins to hand over the "Russian Tsar", exerting various kinds of pressure on the Montenegrins. They were promised the delivery of food, weapons and gunpowder, if they agreed to hand over Stepan. The Montenegrins were not seduced by such promises, and then the Turks sent their strong army against them, but it was defeated. The enemies of Montenegro achieved their goal only with the help of bribery and deceit: the liar Stepan was killed by an assassin.

Negosh was an outstanding man of his time. He maintained close contacts with prominent figures of that era: the enlighteners Vuk Karadzhich and Lyudevit Guy. Negosh is a great poet whose works continue to live in the national consciousness of Montenegrins.

Translated by Igor Kaliganov

\section{BIBLIOGRAPHY}

Petar Petrovih Njegosh u svom vremenu: Zbornik radova. Titograd, 1985.

Ivanoviћ R. Njegosheva poetika i estetika. Novi Sad, 2002.

Vrchevih V.Zhivot Petra II Petroviha Њegosha. Beograd, 2003.

Lavrov P.A. Petr II Petrovich Negosh. Moskva, 1887.

Petar II Petrovich Negosh - mitropolit, reformator, poèt: k 200-letiiu so dnia rozhdeniia. Moskva, 2013. 


\section{ILLUSTRATIONS}

1. Petar P. Negosh in the rank of Metropolitan.

2. A portrait of Petar P. Negosh.

3. Tsetinye monastery.

4. Sima Milutinovich-Saraylya, the teacher of Petar P. Negosh.

5. The cover of the first edition of "The Ray of the Microcosm," 1845.

6. The cover of the first edition of "The Mountain Crown," 1847.

7. The cover of the first edition of "Imposter Stepan the Small," 1851.

8. The Mausoleum of Petar P. Negosh in Lovchen, Montenegro.

9. Monument to Petar P. Negosh in the center of Belgrade, 1994.

10. Bank-note with a portrait of Petar P. Negosh. 